\title{
Genetic Analyses Demonstrate That Bone Morphogenetic Protein Signaling Is Required for Embryonic Cerebellar Development
}

\author{
Lihua Qin, ${ }^{1,4}$ Lara Wine-Lee, ${ }^{1,3}$ Kyung J. Ahn, ${ }^{1}$ and E. Bryan Crenshaw III ${ }^{1,2,3}$ \\ ${ }^{1}$ Mammalian Neurogenetics Group, Center for Childhood Communication, Division of Pediatric Otolaryngology, The Children's Hospital of Philadelphia, \\ and ${ }^{2}$ Department of Otorhinolaryngology: Head and Neck Surgery and ${ }^{3}$ Neuroscience Graduate Group, University of Pennsylvania School of Medicine, \\ Philadelphia, Pennsylvania 19104, and ${ }^{4}$ Department of Anatomy, Peking University Health Science Center, Beijing, China 100083
}

The cerebellum has been a useful model for studying many aspects of neural development because of its relatively simple cytoarchitecture and developmental program. Yet, the genetic mechanisms underlying early differentiation and patterning of the cerebellum are still poorly characterized. Cell expression studies and culture experiments have suggested the importance of bone morphogenetic proteins (BMPs) in development of specific populations of cerebellar neurons. Here, we examined mice with targeted mutations in the BMP type I receptor genes Bmprla and Bmpr1b, to genetically test the hypothesis that BMPs play an inductive role in the embryogenesis of cerebellar granule cells. In Bmpr 1a;Bmpr $1 b$ double knock-out mice, severe cerebellar patterning defects are observed resulting in smaller cerebella that are devoid of foliation. In mutants containing either single BMP receptor gene mutation alone, cerebellar histogenesis appears normal, thereby demonstrating functional redundancy of type I BMP receptors during cerebellar development. Loss of BMP signaling in double mutant animals leads to a dramatic reduction in the number of cerebellar granule cells and ectopic location of many of those that remain. Molecular markers of granule cell specification, including Math1 and Zic1, are drastically downregulated. In addition, Purkinje cells are disorganized and ectopically located, but they appear to be correctly specified. Consistent with the interpretation that granule cells alone are affected, phosphorylated Smad1/5/8 is immunolocalized predominantly to granule cell precursors and not appreciably detected in Purkinje cell precursors. This study demonstrates that BMP signaling plays a crucial role in the specification of granule cells during cerebellar development.

Key words: bone morphogenetic protein receptor type I; Cre-mediated conditional Bmprla knock-out; Bmpr1b mutant; cerebellar development; external granular layer; granule cells; Purkinje cells

\section{Introduction}

Unlike other regions of the CNS, where all neuronal proliferation occurs at the primitive ventricular neuroepithelium, the cerebellum develops from a secondary germinal zone, the external granular layer (EGL), that forms from the primary cerebellar ventricular zone. The EGL originates from the rostral rhombic lip at the interface between the roof plate and the dorsal neuroepithelium of rhombomere 1 (Alder et al., 1996; Sotelo, 2004). Rostral rhombic lip progenitors will become granule cell progenitors and some ventral neurons in the rostral hindbrain region (Wingate and Hatten, 1999; Lin et al., 2001). Granule cell precursors migrate tangentially to cover the superficial zone of the cerebellar primordium and eventually spread across the roof of the anlage to form

Received Aug. 1, 2005; revised Dec. 17, 2005; accepted Dec. 21, 2005.

We gratefully acknowledge Drs. J. Johnson, M. Goulding, and A. McMahon for probes used in our studies. We also thank Drs J. Davis and N. Solowski for critical discussions and comments on this manuscript. We also appreciate X. Y. Teng, R. D. Richardson, and F. Passero for technical assistance.

Correspondence should be addressed to Dr. E. Bryan Crenshaw III, Mammalian Neurogenetics Group, Center for Childhood Communication, The Children's Hospital of Philadelphia, 34th and Civic Center Boulevard, Philadelphia, PA 19104. E-mail: crenshaw@email.chop.edu.

DOI:10.1523/JNEUROSCI.3202-05.2006

Copyright $\odot 2006$ Society for Neuroscience $\quad$ 0270-6474/06/261896-10\$15.00/0 the EGL. Postmitotic granule cells migrate via an inward radial pathway and reach their final destination to form the internal granule cell layer (IGL) (for review, see Sotelo, 2004).

Bone morphogenetic protein (BMP) signaling has been proposed to induce the generation of granule neuron progenitors that migrate from the rhombic lip to populate the EGL (Alder et al., 1999). BMPs bind to heteromeric receptor complexes that contain type I and type II serine/threonine protein kinase receptor subunits, which are both essential for signal transduction (Wrana et al., 1994; Hogan, 1996; ten Dijke et al., 1996; WeisGarcia and Massague, 1996). In the mouse, the type I receptors are encoded by two genes, Bmprla and Bmpr $1 b$. Bmpr $1 a$ is nearly ubiquitously expressed in embryos and adults (for review, see Ebendal et al., 1998; Zhao, 2003). Bmpr1b demonstrates a more limited expression domain. Genetic analyses demonstrate that $B m p r 1 b$ has both unique and redundant functions during development (Yi et al., 2000; Wine-Lee et al., 2004).

BMP receptors mediate their signals intracellularly via the SMAD proteins, which are the downstream targets of TGF $\beta$ superfamily signaling (for review, see Zhao, 2003) or via other intracellular signaling pathways, including mitogen-activated protein kinases, JNK (c-Jun $\mathrm{NH}_{2}$-terminal kinase), Rho, Rac, and 
others (for review, see von Bubnoff and Cho, 2001; Derynck and Zhang, 2003). In the classical model, the receptor SMADs (RSmads) SMAD1, 5, and 8 transduce BMP signals. After ligand binding, the heteromeric BMP receptor complexes phosphorylate the R-Smad proteins. The R-Smad proteins then bind to a common Co-Smad, Smad4, and the complex translocates to the nucleus after phosphorylation to directly control gene expression.

Although BMP signaling may play roles in both the specification and differentiation of granule cells, genetic analyses of BMP function during neural tube development have been hampered by the early embryonic lethal phenotype of knock-outs in several BMP genes and their receptors. To address the mechanism of action of BMPs in the developing cerebellum genetically, we have undertaken analyses of conditional knock-out mutants that eliminate BMP receptor signaling in the neural tube. In our mutants, the function of type I BMP receptor genes Bmprla and Bmpr1b in the developing cerebellum has been abrogated. These studies demonstrate that BMP signaling is necessary for the development of granule cell precursors, thus providing a strong basis for understanding the molecular control of granule neuron specification and differentiation.

\section{Materials and Methods}

Generation and identification of conditional knock-out mice. The Bmprla conditional knock-out mice were generated as described previously (Ahn et al., 2001; Mishina et al., 2002), using the AB-1 embryonic stem (ES) cell line. K. Lyons (University of California, Los Angeles, Los Angeles, CA) (Yi et al., 2000) generously provided the Bmprlb knock-out pedigree, which was generated with the CCE ES cell line. Double mutants, containing a conditional knock-out of Bmprla in the neural tube and a classical knock-out of Bmprlb, were generated as described previously (Wine-Lee et al., 2004). The conditional knock-out was induced using a pedigree of mice, Bcre-32, in which the neural tube-specific transcriptional regulatory elements of the POU-domain gene, Brn4/Pou3f4, are used to drive the expression of the Cre transgene (Heydemann et al., 2001), which were generated on a CD-1 strain background. Because of the complexity of genotypes required to generate double mutant embryos, littermates that were completely wild type were not produced. Therefore, we refer to unaffected littermates as "normal" controls. Because the pedigrees have been maintained by intercross breeding, the background strain is a mixture of strains, including C57BL/6J, CD-1, and the 129/Sv strains used to generate the $\mathrm{AB}-1$ and $\mathrm{CCE}$ ES cell lines.

Tail tissues of mice were collected for DNA extraction, and embryos and pups were genotyped using PCR analysis. Primers for genotyping the wild-type allele of Bmpr1b, for the null allele of Bmprla, and for Bcre-32 have been described previously (Wine-Lee et al., 2004).

Embryos were dissected from the uterus at different stages, as indicated in the text. Entire brains were dissected and washed in PBS at $4^{\circ} \mathrm{C}$, followed by fixation in $4 \%$ paraformaldehyde at $4^{\circ} \mathrm{C}$ overnight. Neonatal [postnatal day $0(\mathrm{P} 0)$ ] mice were anesthetized with isoflurane and perfused transcardially with a $0.1 \mathrm{M}$ PBS solution, $\mathrm{pH} 7.3$, followed by $4 \%$ paraformaldehyde, and the brains were removed from the calvarium. Further fixation was accomplished in $4 \%$ paraformaldehyde at $4^{\circ} \mathrm{C}$ overnight. Fixed embryos were treated in $30 \%$ sucrose at $4^{\circ} \mathrm{C}$ overnight, embedded in OCT compound (Tissue-Tek; Pelco International, Redding, CA), and cryosectioned at $25 \mu \mathrm{m}$ for in situ hybridization and immunohistochemical analyses. For paraffin embedding, fixed brains were dehydrated, processed in paraffin, and embedded via standard procedures. Sections $(7 \mu \mathrm{m})$ were cut for histological analysis. We restricted most of our analyses to sections of medial regions that contained choroid plexus in the fourth ventricle. At least four animals of each age and genotype were examined.

In situ hybridization. Digoxygenin probes for nonradioactive in situ hybridization were synthesized as run-off transcripts from linearized plasmid templates using RNA polymerases (T3, T7, and Sp6) according to the manufacturer's protocol (Roche, Basel, Switzerland). The anti- sense probes used include the following: Math1 (J. Johnson, Southwestern Medical Center, Dallas, TX), Pax6 (M. Goulding, Salk Institute, San Diego, CA), and Shh (A. McMahon, Harvard University, Boston, MA). In situ hybridization and visualization of signal were accomplished as described previously (Wilkinson, 1992).

Immunohistochemistry and histology. Immunohistochemistry was performed by incubation overnight at $4^{\circ} \mathrm{C}$ with $150 \mathrm{kDa}$ rabbit antineurofilament (1:200; Chemicon, Temecula, CA), rabbit anti-phosphohistone H3 (1:200; Upstate Biotechnology, Lake Placid, NY), rabbit anticalbindin D-28K (1:200; Chemicon), mouse monoclonal anti-TAG-1/ 4D7 (1:50; Developmental Studies Hybridoma Bank, University of Iowa Iowa City, IA), mouse monoclonal anti-Tuj1 (1:500; Covance, Denver, PA), and rabbit anti-Zic1/2 (1:400; a gift from R. Segal, Dana Farber Cancer Institute, Boston, MA). For double-label immunohistochemistry, primary antibodies were combined for overnight incubation at $4^{\circ} \mathrm{C}$. Primary antibody dilutions were incubated overnight in $\mathrm{PBS} / 2 \%$ goat serum $/ 0.1 \%$ Triton X-100. Fluorescently labeled secondary antibodies included goat anti-rabbit IgG rhodamine, goat anti-mouse IgG FITC, and goat anti-rabbit IgM FITC (Jackson Immunoresearch, West Grove, PA). After a final PBS wash, nuclei were visualized using 4',6-diamidino2-phenylindole (DAPI) staining.

Phospho-Smad1/5/8 immunohistochemical analyses were performed according to previously published methods using immunoperoxidase labeling (Ahn et al., 2001; Wine-Lee et al., 2004) or by a modification for immunofluorescent labeling, using an antibody dilution of 1:5000. For double-label immunohistochemical analyses, the secondary antibody used to visualize Zic1/2 or calbindin was goat anti-rabbit IgG conjugated to rhodamine.

$\beta$-Galactosidase immunohistochemical staining was performed on 25 $\mu \mathrm{m}$ cryosections that had been immersion fixed for $2 \mathrm{~h}$ in the case of $13.5 \mathrm{~d}$ postcoitus (dpc). P0 samples were postfixed for $2 \mathrm{~h}$ after transcardial perfusion. Rabbit $\beta$-galactosidase antibody (1:1000; Rockland, Gilbertsville, PA) was incubated at $4^{\circ} \mathrm{C}$ overnight, and the Vectastain $\mathrm{ABC}$ kit (Vector Laboratories, Burlingame, CA) and TSA Indirect Tyramide Signal Amplification kit (PerkinElmer Life Science, Norwalk, CT) were used to visualize the signal.

For histological analyses, paraffin sections of neonatal mice brains were Nissl stained using thionin. Histological staining with X-gal to visualize lacZ expression was described previously (Phippard et al., 1999).

Terminal deoxynucleotidyl transferase-mediated dUTP nick endlabeling assays and quantitative analyses. Apoptosis in the developing brain was assessed by the terminal deoxynucleotidyl transferasemediated dUTP nick end-labeling (TUNEL) assay (Roche). TUNEL analyses were accomplished using $25 \mu \mathrm{m}$ cryosections and processed according to published protocols (Grinspan et al., 1998).

Quantitative analyses of TUNEL staining were undertaken by outlining a box of defined dimensions on a digital image of the section to be analyzed and by counting total (DAPI-labeled) and TUNEL-positive cells (or phospho-histone $\mathrm{H} 3$ for proliferation assays). On $13.5 \mathrm{dpc} \mathrm{sec-}$ tions, a line representing one side of the box was drawn that bisected the angle between the mesencephalon and the cerebellum. The second side of the box was formed by drawing a line tangential to the outer surface of the cerebellum starting at the intersection of the first line with the neural tube. The last two sides of the parallelogram were formed by drawing lines parallel to the first line at a distance of $170 \mu \mathrm{m}$ and parallel to the second line at a distance of $60 \mu \mathrm{m}$. On P0 sections, a rectangular box $(500 \times 300 \mu \mathrm{m})$ was outlined in the deep cerebellum, and the percentage of positive cells within the box was quantified. At least three animals were analyzed of each genotype. Statistical comparisons were tested for significance using a one-tailed Student's $t$ test.

\section{Results}

\section{Cre-mediated gene rearrangements are induced during} cerebellar development

To determine the spatial and temporal expression of the Bcre-32 pedigree in the cerebellum, we intercrossed the $B$ cre-32 pedigree with the ROSA reporter strain. Cre recombinase induces expression of the lacZ gene from the ROSA reporter locus, thereby 


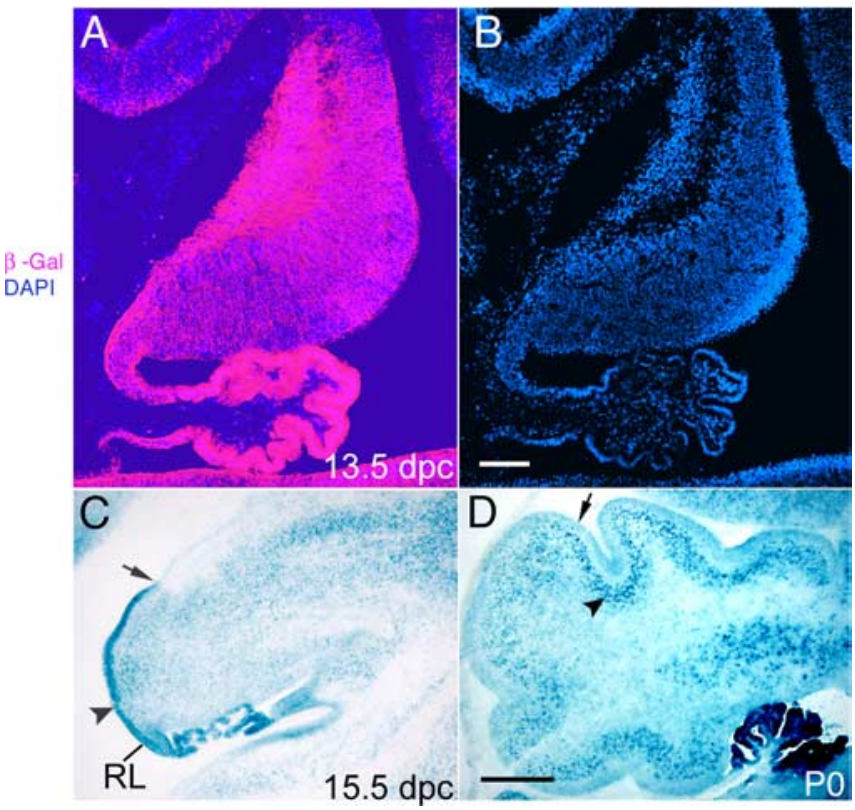

Figure 1. Cre-mediated recombination of the ROSA26 reporter by the Bcre-32 transgene is detected in the cerebellum. $A$, At $13.5 \mathrm{dpc}$, immunohistochemical staining for $\beta$-galactosidase ( $\beta$-Gal) shows lacZ expression in the vast majority of cells throughout the cerebellar anlage. $\boldsymbol{B}$, DAPI staining shows the density of cells within the cerebellum. C, At $15.5 \mathrm{dpc}$, Cre-mediated lac $Z$ expression is detected strongly in the EGL, because of the high cell density in this region (arrowhead). Note that the EGL extends from the rhombic lip (RL) but only covers part of the cerebellar cortex at this stage of development (ending at the arrow). D, Postnatally, Cre-mediated lac $Z$ expression is found in the EGL (arrow) and the PCL (arrowhead). Scale bars: $\boldsymbol{B}, 100 \mu \mathrm{m} ; \boldsymbol{D}, 250$ $\mu \mathrm{m}$.

marking those cells in which Cre-mediated gene rearrangements have occurred (Soriano, 1999). As shown in Figure 1, Bcre-32mediated expression of the ROSA reporter is detected throughout cerebellar development, using both histochemical staining with X-gal (Fig. 1C,D) and immunohistochemical analyses (Fig. $1 A)$. At $13.5 \mathrm{dpc}$, the lac $Z$ gene product $\beta$-galactosidase is expressed in the majority of cerebellar anlage cells (Fig. $1 A$ ). At 15.5 $\mathrm{dpc}$, the EGL and choroid plexus show uniform blue X-gal staining (Fig. 1C). Postnatally, the EGL and Purkinje cell layers (PCLs) appear uniformly stained (Fig. $1 D$ ). These results demonstrate that Cre-mediated gene rearrangements are induced in the vast majority of cells in the embryonic cerebellum.

\section{Cerebella are abnormally formed in Bmpr1a;Bmpr1b double knock-out mutants}

Because of the early embryonic lethality caused by mutations in the Bmprla gene, we have used the Cre/loxP conditional knockout approach to generate a conditional knock-out of Bmprla (Ahn et al., 2001; Wine-Lee et al., 2004). Null mutations of the Bmprla gene are generated specifically in the neural tube using a Cre-expressing pedigree, Bcre-32. In this pedigree, Cre expression is directed to the neural tube using the $5^{\prime}$ flanking region of the Brn4/Pou3f4 gene (see Materials and Methods for details). To generate a double knock-out of both Bmprla and Bmprlb, we intercrossed the conditional Bmprla knock-out with a classical $B m p r 1 b$ knock-out. In double knock-out animals, cerebella are smaller in size and lack foliation (Fig. $2 B, D$ ) compared with normal P0 neonates (Fig. 2A,C). At P0, the cerebellum in the normal animal is still immature, but spatial organization of the different cell types is present (Fig. 2C,E). Defined layers include the granule cell progenitors in the EGL, the parallel fibers from newly matur-

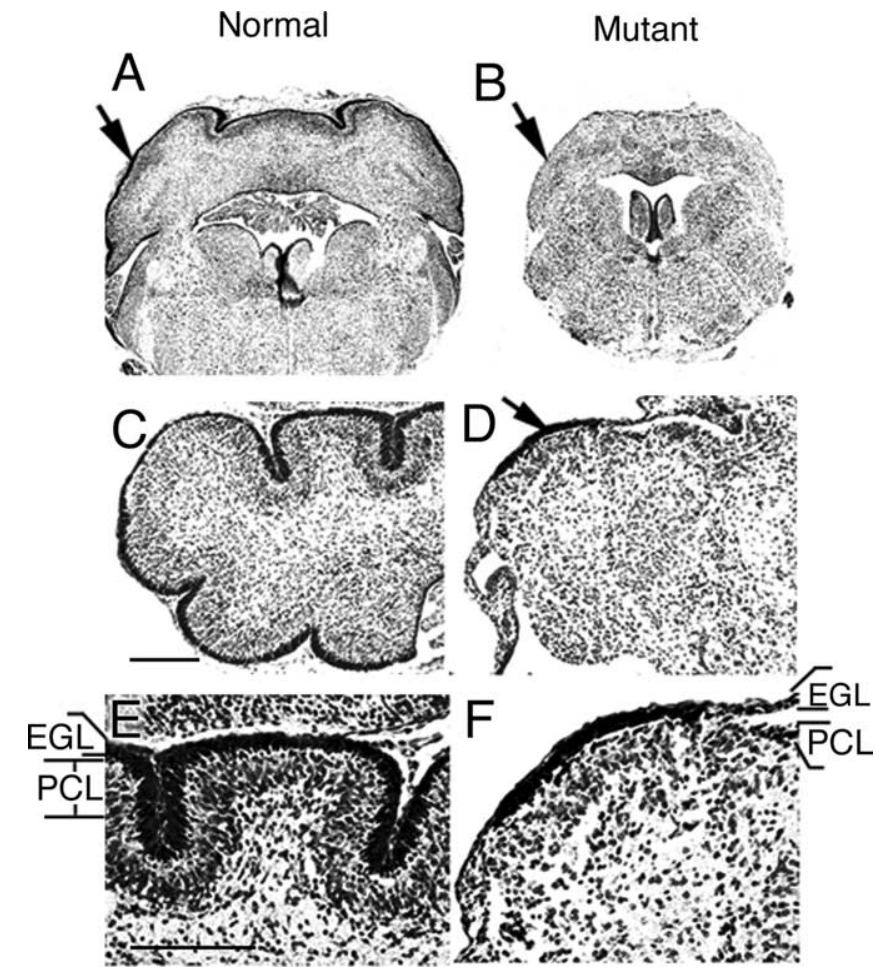

Figure 2. Abnormal formation/development of the cerebellum in Bmpr1a;Bmpr1b double knock-out mutants. $\boldsymbol{A}$, Nissl staining on coronal sections shows the normal cerebellum at PO (arrow). $\boldsymbol{B}$, The cerebellum of the mutant mouse is smaller in size at P0 (arrow). $\boldsymbol{C}, \boldsymbol{E}$, Nissl staining show defined layers including the $E G L$ and $P C L$ in normal $P 0$ neonates. The $M L$ is the cell-sparse layer between the EGL and PCL. $\boldsymbol{D}, \boldsymbol{F}$, In the mutant cerebellum, disruption of the layered organization is observed. Only a small region with the thickened EGL (arrow) is observed, but most of the mutant cerebellum completely lacks the EGL and PCL, the presumptive position of which is indicated in $\boldsymbol{F}$. $\boldsymbol{E}$, High-magnification view of $\boldsymbol{C}$. $\boldsymbol{F}$, High-magnification view of $\boldsymbol{D}$. Scale bars: $\boldsymbol{C}, \boldsymbol{E}, 250 \mu \mathrm{m}$.

ing granule cells forming the molecular layer (ML), and the PCL. At this stage of development, the ML and the PCL are not mature, but they can be visualized by histological staining. In the double knock-out mutants, most regions of the cerebellum completely lack a granule cell layer. Furthermore, the ML and the PCL are disorganized. A small region on the dorsal side of the mutant cerebella has a more normal layer structure with a clear EGL, ML, and PCL, but not as tightly packed and uniform as in normal neonates (Fig. 2D,F). Cerebella in either Bmprla or Bmprlb knock-outs alone are apparently unaffected (data not shown). The morphological defects in mutant cerebellum result in decreased size, loss of foliation, and lack of an EGL.

\section{BMP signaling is abrogated in the cerebella of}

\section{Bmpr1a;Bmpr1b double knock-out mutants}

To assess directly whether BMP signaling has been abrogated, phosphorylation of SMAD (phospho-SMAD1/5/8) was examined by immunohistochemistry. R-Smads are phosphorylated by type I BMP receptor proteins, BMPR-IA and BMPR-IB, and the phosphorylated SMAD molecules can be detected using immunohistochemical analyses with antibodies specific for the phosphorylated forms (Ahn et al., 2001; Wine-Lee et al., 2004). As early as $10.5 \mathrm{dpc}$, phospho-SMAD-immunopositive cells are detected at the rostral rhombic lip in normal mice (Fig. 3A, arrow), but the signal is lost in the double knock-out mutants (Fig. $3 B$, arrow). By $13.5 \mathrm{dpc}$, phospho-SMAD-positive cells are detected throughout the neuroepithelium of the cerebellar anlage (Fig. $3 C$, 
Normal

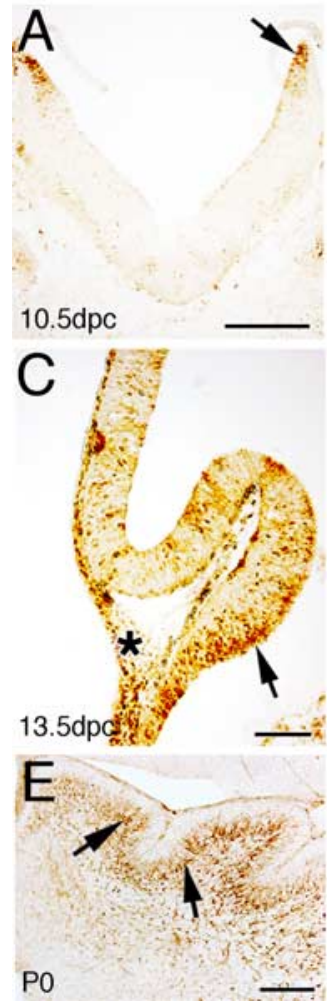

Mutant
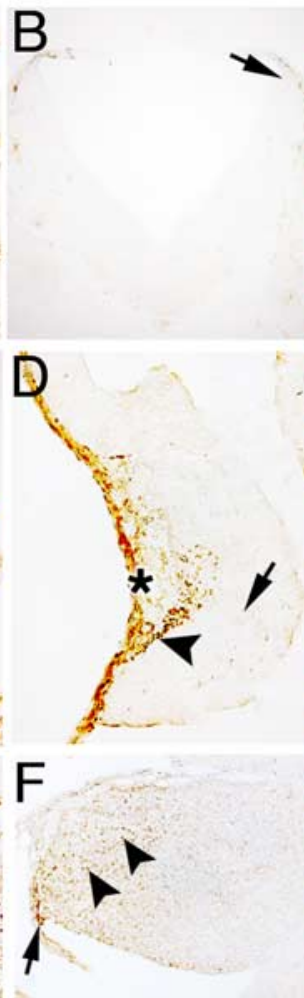
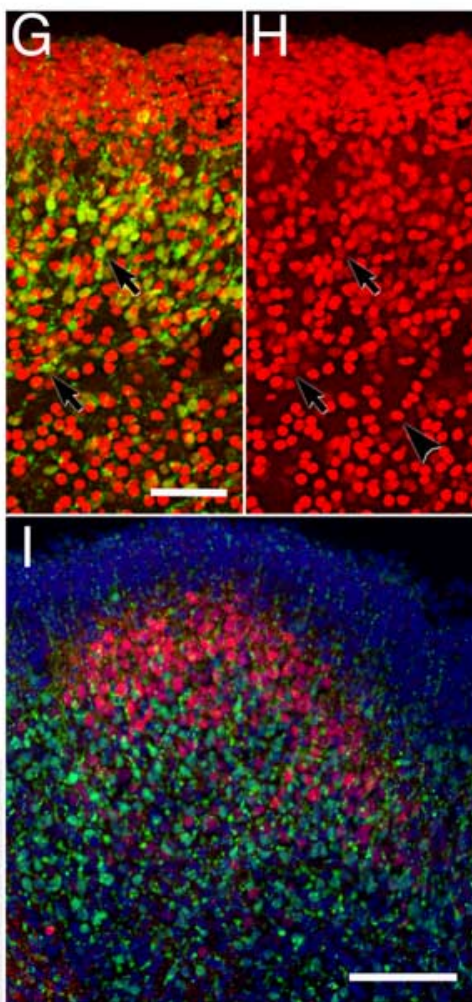

Figure 3. Phospho-SMAD immunolabeling demonstrates loss of BMP signaling in the cerebellum of Bmpr $1 a ; B m p r 1 b$ knockout mice. $\boldsymbol{A}$, Immunoreactive cells are detected in the rostral rhombic lip at $10.5 \mathrm{dpc}$ in normal mice (arrow). $\boldsymbol{B}$, In mutant embryos, phospho-SMAD immunostaining is lost in the rostral rhombic lip (arrow). C, At $13.5 \mathrm{dpc}$ in normal embryos, immunoreactive cells are detected in the ventral cerebellar anlage within and above the neuroepithelium (arrow). In addition, immunoreactive cells are located dorsally in leptomeninges (asterisk). $\boldsymbol{D}$, In the mutant mouse, phospho-Smad immunostaining demonstrates that BMP signaling has been abrogated in the vast majority of cells within the cerebellar anlage (arrow). However, a few positive cells are located along the dorsal side (arrowhead) of the neural tube in a region where the granule cells are migrating to form the EGL. Immunolabeling in the leptomeninges is unaffected (asterisk). $\boldsymbol{E}$, Postnatally, phospho-SMAD-immunolabeled cells are detected in migrating granule cells and in the IGL of normal mice, which lies deep to the PCL (arrows). $\boldsymbol{F}$, In the PO mutant, phospho-Smad immunolabeling is drastically reduced. However, a few labeled cells are detected within or proximal to the rhombic lip (arrow) and a few cells deep in the cerebellum (arrowheads). G, Double immunolabeling with phospho-SMAD (green) and Zic1/2 (red) in the cerebellum of a normal mouse at PO. Double immunostained cells are located predominantly in the IGL and in migrating granule cells (arrows). However, a few cells are detected in the EGL (the dense cell layer located at the top of the panel). $\boldsymbol{H}$, Area depicted in $\mathbf{G}$ showing immunostaining for Zic1/2 alone to demonstrate that two classes of Zic1/2-immunopositive cells can be detected that label intensely (arrowhead) or lightly (arrows). I, Double immunolabeling with phospho-SMAD (green) and calbindin (red) in a section of the cerebellum of normal mice at PO counterstained with DAPI (blue). Virtually no double immunostained cells are detected in the cerebella, whereas single calbindin-labeled positive Purkinje cells are found in the cerebella. These results demonstrate that phospho-SMAD is detected in granule cells that have migrated away from the proliferative zone of the EGL and are in the process of differentiating into mature granule cells. Scale bars: $\boldsymbol{A}, 250 \mu \mathrm{m} ; \boldsymbol{C}, \boldsymbol{E}, \boldsymbol{I}, 100 \mu \mathrm{m} ; \boldsymbol{G}, 50 \mu \mathrm{m}$. PSMAD, Phospho-SMAD.

arrow), as well as the overlying leptomeninges (Fig. 3C, asterisk). In the double knock-out embryos, phospho-SMAD immunolabeling is essentially undetectable in the neuroepithelium (Fig. 3D, arrow), although a few immunopositive cells are detected along the dorsal side of the cerebellar anlage (Fig. 3D, arrowhead). Phospho-Smad immunolabeling is unaffected in the overlying leptomeninges (Fig. 3D). In P0 neonates, phospho-SMADimmunopositive cells are found primarily in migrating granule cells and the IGL of normal mice (Fig. 3E, arrows). In P0 double knock-out mutants, only a small localized region of the cerebellum contains immunopositive cells (Fig. $3 F$, arrow), and a few immunopositive cells are scattered in the deep cerebellum (Fig. $3 F$, arrowheads). The total number of immunopositive cells is drastically reduced in mutants. Single knock-out mutants in either the Bmprla or Bmprlb gene do not lead to a loss of phospho-SMAD

\section{Ny}

\section{$\frac{\mathrm{n}}{\mathrm{n}}$}

signaling (data not shown), demonstrating that both type I receptors must be eliminated to abrogate BMP signaling in the cerebellum.

To clarify which cell types are immunopositive for phospho-SMAD, double immunostaining of phospho-SMAD and Zic1/2, a marker of granule cells, and calbindin, a Purkinje cell marker, was performed in normal P0 cerebella. Granule cells that are migrating and those that are located in the IGL labeled with both phospho-SMAD and Zic1/2, as well as some scattered in the deep cerebellum (Fig. 3G). Two classes of Zic1/2immunopositive cells that are immunostained intensely (Fig. $3 \mathrm{H}$, arrowhead) or lightly (Fig. $3 H$, arrows) can be detected. Interestingly, the majority of cells that are immunolabeled for phospho-Smad are lightly immunostained for Zic1/2 (compare cells pointed out by arrows in Fig. $3 G, H)$. Cells labeled with both phosphoSMAD and calbindin are rarely, if ever, detected in the cerebellum (Fig. 3I), indicating that the vast majority or all of the phospho-SMAD-immunopositive cells are granule cells. These data demonstrate that BMP signaling is completely abrogated in the rhombic lip at $10.5 \mathrm{dpc}$ in double mutant embryos and is drastically reduced at later fetal and neonatal stages.

\section{Cerebellar granule cell development is disrupted in the double \\ knock-out mutant}

To analyze the changes in the cytoarchitecture of the cerebellum, we examined the two principal neuronal populations in the cerebellum: the granule cells and the Purkinje cells. Genes encoding the transcription factors, Math1 and Pax6, label the EGL (Ben-Arie et al., 1997; Engelkamp et al., 1999; Lin et al., 2001). In normal littermates at $11.5 \mathrm{dpc}$, the expression of Math1 is detected in cells that lie in the dorsolateral region of the hindbrain adjacent to the roofplate (Fig. $4 A$, arrow). In double knock-out mutants, Math1 expression is not detected (Fig. $4 B$, arrow). These data demonstrate that molecular marker defects, which ultimately lead to loss of granule cells, are affected at the earliest stages of cerebellar development. In normal P0 neonates, granule cells expressing both Math1 and Pax6 form a discrete layer that is found throughout most of the cerebellar cortex (Fig. 4C,E, arrows). In double mutant neonates, Math1 expression is detected in a thin layer on the outer edge of the cerebellum that corresponds to the region where the EGL would normally form (Fig. $4 D$, arrow). Pax6, in contrast, is expressed only in a small region of the cerebellum, which is consistently detected in the same location (Fig. $4 F$, arrow).

Zic transcription factors are also a marker for granule cells (Aruga et al., 1994; Nagai et al., 1997; Lin et al., 2001). Using antibodies that recognize both Zic1 and Zic2, we have observed 
Normal
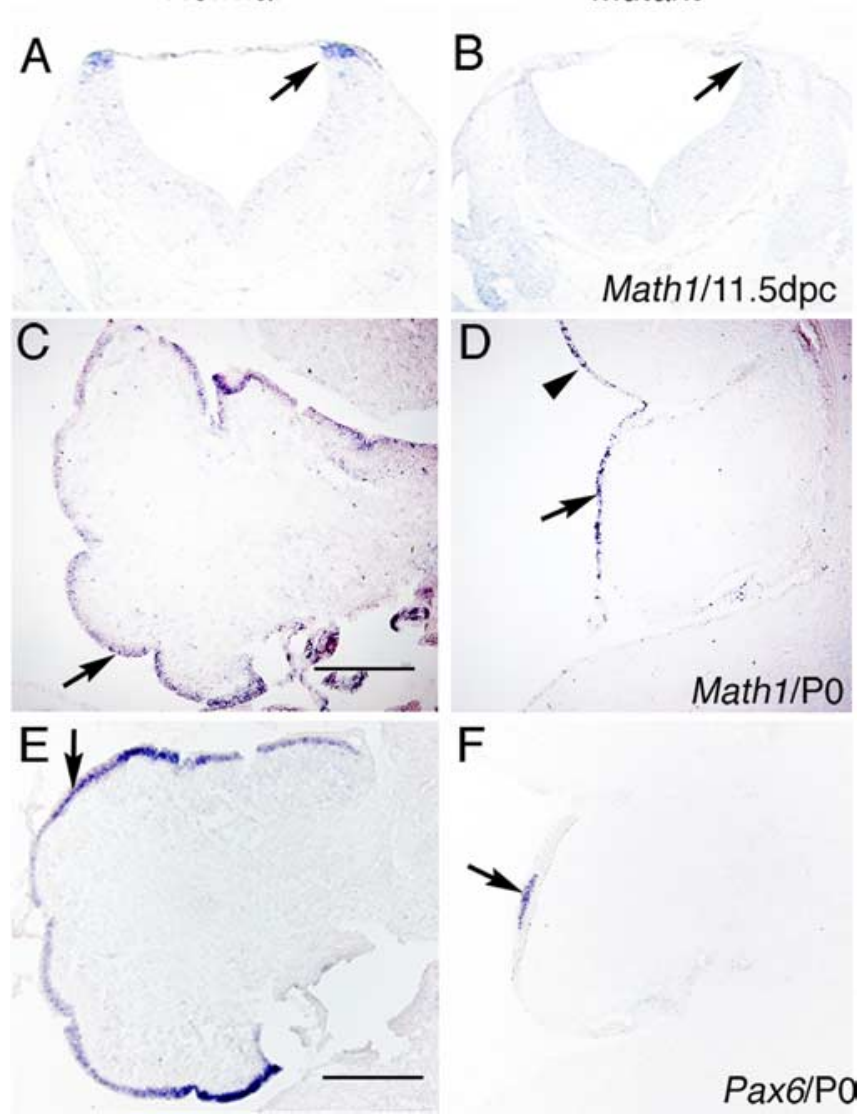

F

Pax6/Pa

Figure 4. Expression of specific markers demonstrates granule cell loss in BMP signaling mutants at $11.5 \mathrm{dpc}$ and $\mathrm{P}$ 0.A-D, In situ hybridization showing Math 1 expression demonstrates loss of granule cell precursors in the rostral rhombic lip and cerebellum of Bmpr1a;Bmpr $1 b$ double knock-out mutants. $A$, Math 1 expression is found in the rostral rhombic lip at $11.5 \mathrm{dpc}$ in normal embryos (arrow). B, Math1 expression is lost at $11.5 \mathrm{dpc}$ in mutant animals (arrow). $\boldsymbol{C}$, Math1 expression is detected in the EGL at P0 in normal embryos (arrow). D, At P0, Math1 expression is detected in a reduced number of cells that are distributed along the entire rim of the cerebellar cortex where the EGL would normally form (arrow) and into the midbrain, which does not normally express Math1 (arrowhead). E, Pax6 expression is detected in the EGL of normal embryos at $\mathrm{PO}$ (arrow). $\boldsymbol{F}$, In mutants at $\mathrm{PO}, \mathrm{Pax} 6$ expression is lost in most regions with the exception of a small region that corresponds to the region of the thickened, more normal EGL observed in the mutants (arrow). Scale bars: $\boldsymbol{C}, \boldsymbol{E}, 250 \mu \mathrm{m}$.

that Zic1/2-immunopositive cells are drastically reduced in number in knock-out mice compared with normal mice (Fig. 5). At $13.5 \mathrm{dpc}$, when the EGL begins to form (Ramon y Cajal, 1889; Hatten and Heintz, 1995), Zic1/2-immunopositive cells are arranged in a wide layer on the ventral side of cerebellum in the normal embryos (Fig. 5A, arrow). However, in the double mutants, there are only a few cells expressing Zic1/2 genes in this location (Fig. 5B, arrow). At P0, granule cells form a compact layer in the EGL of normal neonates (Fig. $5 C$, arrow) and are also located deep within the cerebellum (Fig. $5 C$, arrowhead). In double knock-out neonates, the number of granule cells in both of these areas is drastically decreased in the cerebellum (Fig. $5 D$, small arrow and arrowhead). In addition, some $\mathrm{Zic1} / 2$ immunopositive cells are ectopically located in the inferior colliculus (Fig. 5D, large arrows), indicating that the migration of granule cells may be affected in mutants.

To determine whether the maturation of granule cells is disturbed in mutant cerebella, we immunostained with tubulinassociated glycoprotein 1 (TAG-1), a differentiation marker that

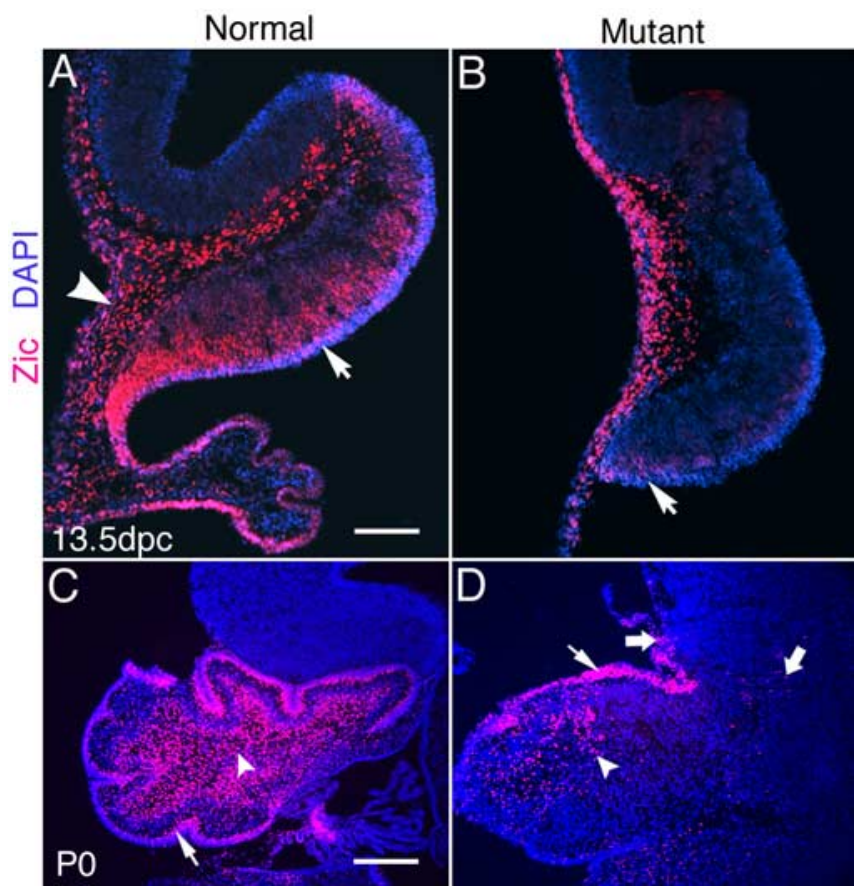

Figure 5. Expression of Zic1/2 in the cerebellum at $13.5 \mathrm{dpc}$ and PO. A, Zic1/2-labeled cells form a wide layer in the ventral side of the cerebellum in the normal mouse at 13.5dpc (arrow). Expression is also detected in the leptomeninges covering the neural tube and the choroid plexus (arrowhead). $\boldsymbol{B}$, In $13.5 \mathrm{dpc}$ mutant embryos, Zic1/2-labeled cells are detected predominantly in the leptomeninges and extra-neural tube tissues, except for light staining just above the neuroepithelium on the ventral side of the cerebellum (arrow). C, Zic1/2-labeled cells are found in the inner EGL (arrow) and deep in the cerebellum in normal mice at PO (arrowhead). The vast majority of Zic1/2-labeled cells are localized in the cerebellum of normal embryos. $\boldsymbol{D}$, The number of Zic1/2-labeled cells is drastically decreased both in the EGL (small arrow) and deep in the cerebellum (arrowhead) of the double knock-outs at PO. Some Zic1/2-labeled cells migrate into the mesencephalon in mutants (large arrows). Scale bars: $\boldsymbol{A}, 100 \mu \mathrm{m} ; \boldsymbol{C}, 250 \mu \mathrm{m}$.

labels granule cell axons and is restricted to the parallel fibers that are forming (Dodd et al., 1988; Furley et al., 1990). TAG-1immunopositive cells are detected at a relatively late stage of granule cell development, as neurons mature (Amy et al., 2001). Double immunostaining with TAG-1 and Zic1/2 clearly demonstrates that the usual juxtaposition of TAG-1-labeled fibers and Zic1/2-labeled granule cells are disorganized in the mutant (Fig. 6 ). This disorganization is particularly prominent in the superior edge of the cerebellum where Zic1/2-immunopositive cells are commingled with TAG-1-immunopositive fibers (Fig. 6B). In normal cerebellum, TAG-1 expression is located in the inner layer of the EGL (Fig. 6A, $C$, arrows). In the mutants, TAG-1 expression is found in only a small region of the inner EGL (Fig. $6 D$, arrow). Also, TAG-1 immunolabeling is detected either as punctate-immunopositive fibers or in clusters in most of the deep region of the mutant cerebellum (Fig. 6D, arrowheads). Some TAG-1 staining is located in the inferior colliculus of mutants (Fig. 6F, arrows), whereas there is no expression in normal mice (Fig. 6E). TAG-1 immunostaining in the inferior colliculus is likely to be derived from the fibers of ectopically expressed Zic1/ 2-immunopositive cells observed in the mutant (see above).

Another early differentiation marker, neuronal-specific $\beta$-tubulin III, is recognized by the antibody Tuj1 (Lee et al., 1990; Easter et al., 1993). Double staining with Zic1/2 and Tuj1 indicates the differentiation state of granule cells in the cerebellum. Mature granule cells double-labeled with $\mathrm{Zic1/2}$ and Tuj1 are 

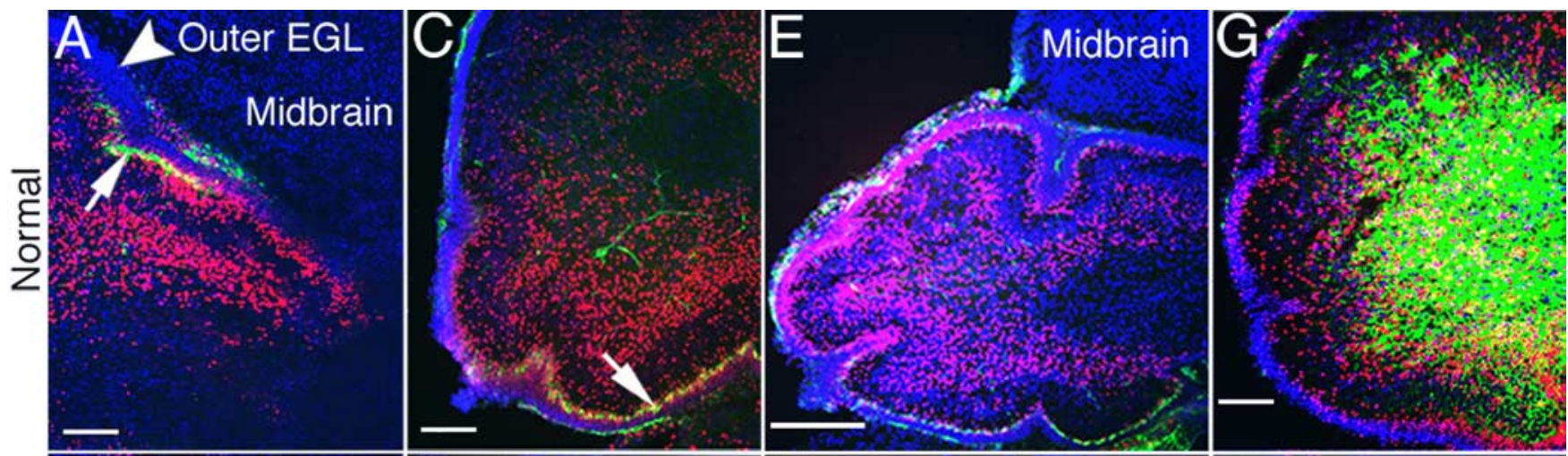

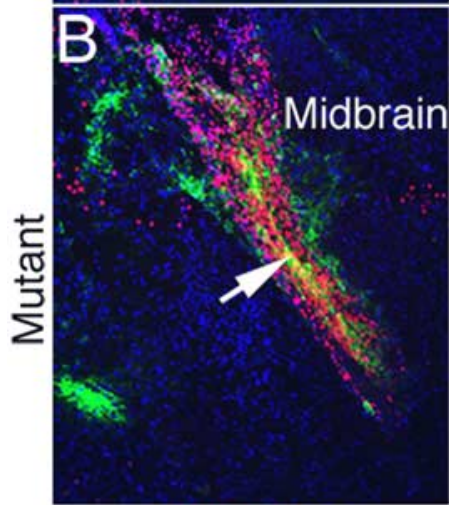

TAG1ZicDAPI

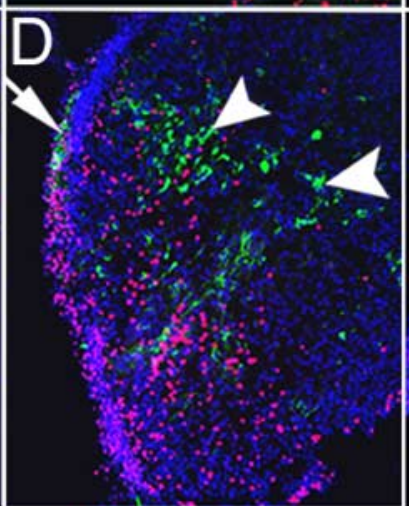

TAG1ZicDAPI

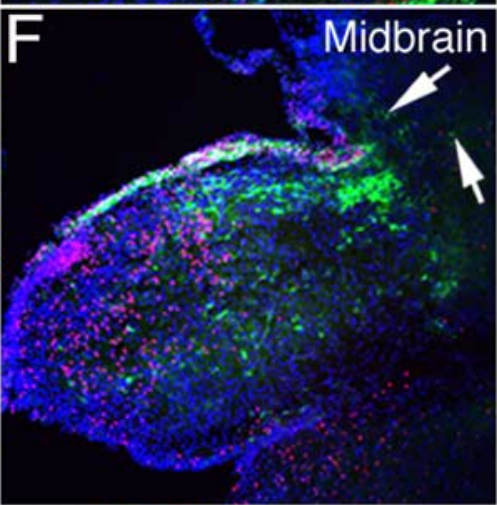

TAG1ZicDAPI

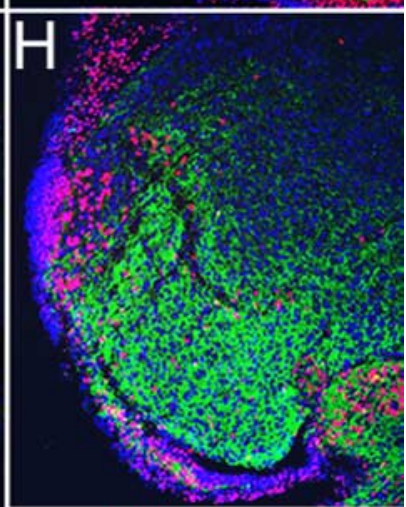

Tuj1ZicDAPI

Figure 6. Differentiation of postmitotic granule cells is disturbed in double knock-outs. $\boldsymbol{A}-\boldsymbol{F}$, Double immunostaining with antibodies directed against TAG-1 (green) and Zic1/2 (red) at P0 in normal and mutant neonates. $A$, TAG-1-labeled fibers are detected in the inner EGL and form a layer in the superior edge in normal neonates (arrow). The outer EGL has no labeled fibers (arrowhead). $\boldsymbol{B}$, TAG-1-labeled fibers mix with Zic1/2-positive cells in the superior edge in the double knock-out mice (arrow). $\boldsymbol{C}$, TAG-1-labeled fibers are also found in the inner EGL at the ventral side of the normal cerebellum (arrow). D, TAG-1-labeled fibers are detected in the deep cerebellum in clusters (arrowheads) with only a small region appearing more normal in mutant cerebellum (arrow). $\boldsymbol{E}$, TAG-1-labeled fibers are restricted to the cerebellum in the normal mouse and are not detected in the midbrain. F, TAG-1-labeled fibers (arrows) and Zic1/2-positive cells are found in the midbrain of the mutant. $\mathbf{G}, \boldsymbol{H}$, Double immunolabeling for Tuj1 (green) and Zic1/2 (red) in the cerebellum at P0. $\mathbf{G}$, Tuj1 expression and more double-labeled cells are located in the deep layers of the normal cerebellum. $\boldsymbol{H}$, Decreased Tuj1 expression and few double-labeled cells are found in the mutant cerebellum. Scale bars: $\boldsymbol{A}, \boldsymbol{C}, \boldsymbol{G}, 100 \mu \mathrm{m} ; \boldsymbol{E}, 250 \mu \mathrm{m}$.

much more numerous in normal neonates than in the mutant (Fig. 6G,H). In total, the analyses of marker gene expression demonstrates that granule cells in the cerebellum are reduced in number, are poorly differentiated, fail to form a complete EGL, and are often ectopically located in mutants.

\section{Effects of the loss of BMP signaling on Purkinje cell development}

To examine the influence of BMP signaling on Purkinje cell development, we perform immunohistochemical analyses for markers that label different stages of Purkinje cell differentiation. Purkinje cell precursors are immunolabeled by calbindin alone (Chedotal and Sotelo, 1992), whereas double labeling with antibodies directed against calbindin and Tuj1 will visualize differentiated Purkinje cells. At $13.5 \mathrm{dpc}$, there are no obvious differences in the localization of Purkinje cells in the mutant cerebella (data not shown). At P0, the mutant neonates demonstrate a markedly different expression pattern. In normal neonates, the vast majority of Purkinje cells migrate beneath the EGL to form the PCL (Fig. 7A, arrow). In P0 mutants, initial fissure formation is evident, but no foliation has occurred. PCL formation is distinct in some regions (Fig. $7 B$, arrow), but in other areas it is disorganized and incorrectly located. Furthermore, calbindin-positive Purkinje cells are found deep in the cerebellum in large clusters (Fig. $7 B$, arrowhead). Finally, Purkinje cells are observed migrating into the mesencephalon (Fig. $7 B$, large arrow).
To assess the status of differentiated Purkinje cells, we examine the cerebella by double labeling with calbindin and Tuj1, a marker for postmitotic neurons (Lee et al., 1990). Two classes of Purkinje cells are identified in both mutant and normal cerebella: a more differentiated cell type that expresses both markers and a precursor cell type that expresses calbindin alone. The differentiated cells are located in the ventral side of the cerebellum beneath the EGL (Fig. 7C, arrows), whereas the cells labeled with calbindin alone are located in the dorsal side of normal cerebella (Fig. 7C, arrowhead). In the dorsal region of normal cerebella, Tuj1 expression follows the foliation. In mutant cerebella, the double-labeled Purkinje cells are located in a small region adjacent to the small patch of EGL that forms in the mutant (Fig. 7D, arrow) and in the deep cerebellum (Fig. 7D, arrowhead). Cells that are double-labeled and those that are labeled with calbindin alone are also located between the cerebellum and inferior colliculus (Fig. 7D, large arrow). Therefore, postmitotic Purkinje cells have migrated to the appropriate location in P0 normal cerebella. In the mutants, these cells have migrated inappropriately to the deep cerebellum. Immature Purkinje cells, in contrast, have not completely migrated into the cerebellum, and some of these cells are detected in the mesencephalon of the mutants. The drastic reduction in differentiated neurons of the cerebellum is also demonstrated with immunostaining for neurofilaments, another marker of differentiated neurons (Fig. $7 E, F)$. 

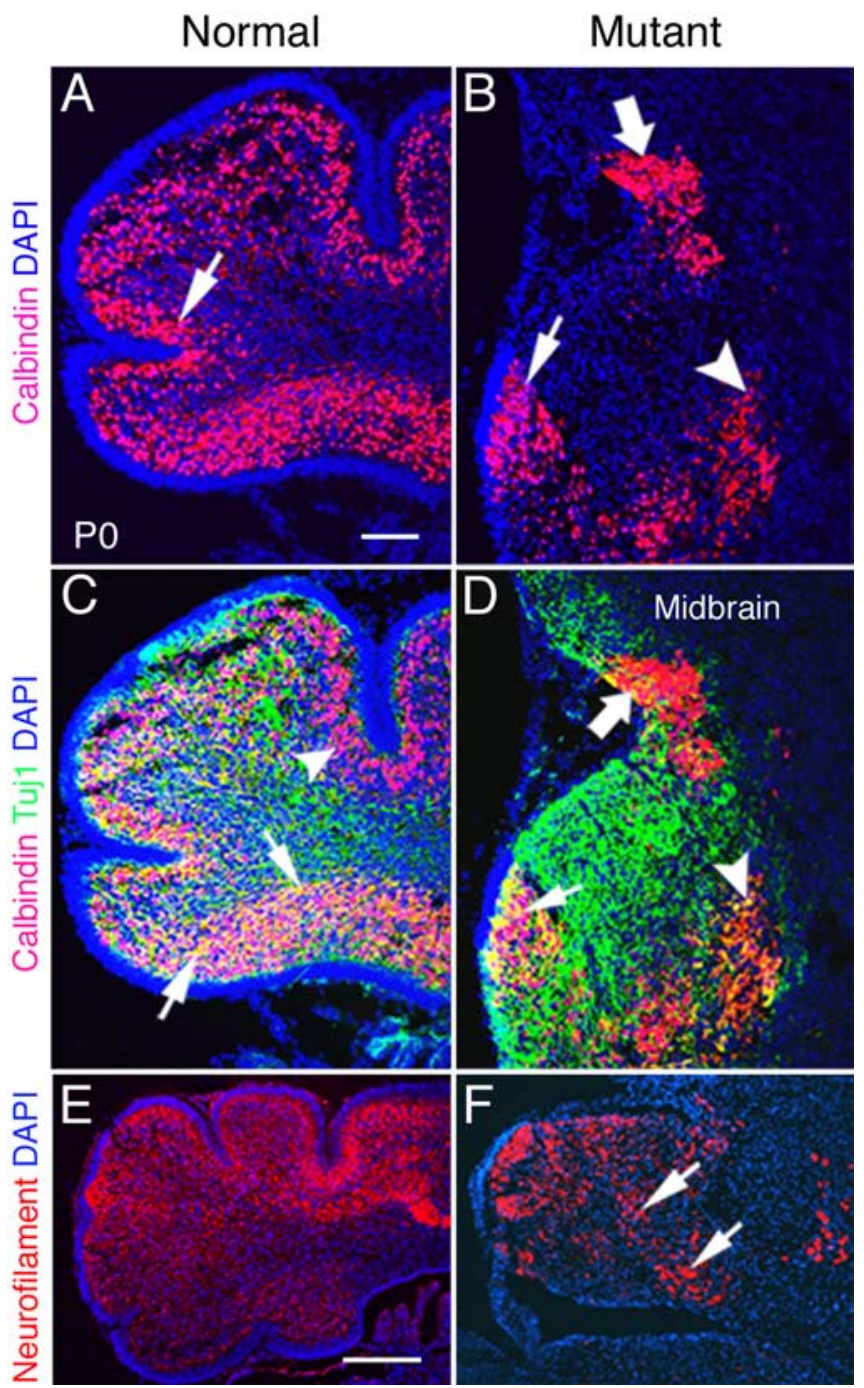

Figure 7. Maturation and migration of Purkinje cells are abnormal in PO Bmpr1a;Bmpr1b knock-outs. $A, A t$ PO, most calbindin-positive Purkinje cells are localized beneath the EGL and form a distinct layer in normal animals (arrow). $\boldsymbol{B}$, However, in mutants, most of the Purkinje cells are localized ectopically in the deep cerebellum (arrowhead) and midbrain (large arrow). Only a small number of cells are localized correctly (arrow). C, D, Detection of calbindin (red) and Tuj1 (green) immunolabeling at P0. C, Double-labeled Purkinje cells are detected in the ventral side of the cerebellum in normal neonates (arrows). Purkinje cells labeled with calbindin alone are detected in the dorsal side of the cerebellum (arrowhead). D, Double-labeled cells are located ectopically in the deep cerebellum (arrowhead) and are present in decreased number in the mutant neonates. Tuj1 expression is disorganized, and some double-labeled cells are located in the midbrain of double knock-out neonates (large arrow). Only some double-labeled cells are localized correctly (small arrow). $\boldsymbol{E}$, In normal PO mice, the majority of cerebellar cells express neurofilament, except those located in the EGL. $\boldsymbol{F}$, Neurofilament expression is detected in the cerebellum in plaques (arrows) with some areas lacking expression in double mutants. Scale bars: $A, 100 \mu \mathrm{m} ; \boldsymbol{E}, 250 \mu \mathrm{m}$.

Loss of cerebellar granule cells associates with both a decrease in proliferation and an increase in apoptosis

The proliferation of granule cell precursors is examined by immunostaining for the mitosis marker phospho-histone H3 (Anton et al., 2004). At $13.5 \mathrm{dpc}$, there are obvious differences in the level of proliferation of granule cell progenitors between normal and double mutant embryos (Fig. 8C) $(p<0.004)$. At P0, labeled cells are much more numerous in the normal cerebellum than in the mutant cerebellum in both granule cells and deep cerebellar neurons (Fig. 8A-C). Cells immunopositive for phospho-histone $\mathrm{H} 3$ are located in the EGL and deep cerebellum. Statistical anal-
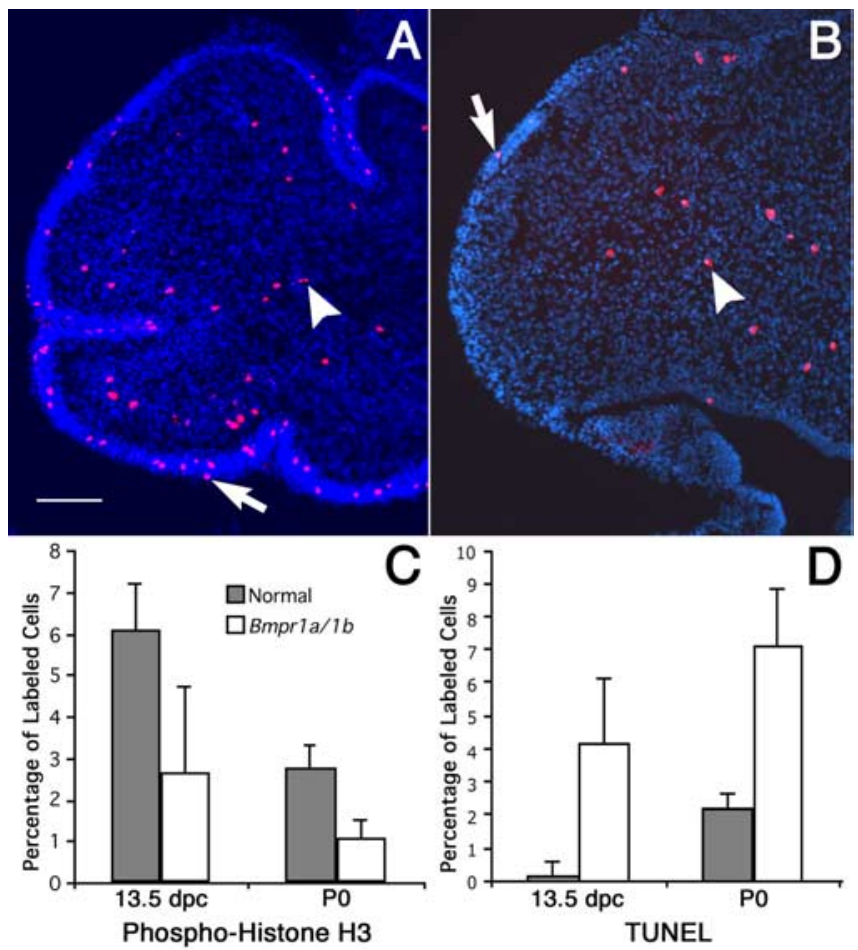

Figure 8. Decreased proliferation and increased apoptosis in Bmpr1a;Bmpr1b double knockout mutants. $A, B$, Phospho-histone $\mathrm{H} 3$ immunolabeling detects proliferating cells at PO. $\boldsymbol{A}$, Phospho-histone H3-labeled cells are found in the EGL (arrow) and deep cerebellum (arrowhead) in normal mice. Scale bar, $100 \mu \mathrm{m} . \boldsymbol{B}$, In double knock-out mutants, the number of phospho-histone H3-positive cells decreases markedly, both in the EGL (arrow) and the deep cerebellum (arrowhead). C, The number of proliferating cerebellar cells decreases by 2.3-fold $(p<0.004)$ at $13.5 \mathrm{dpc}$ and by 2.6 -fold $(p<0.0001)$ in the deep cerebellum at P0. D, A significant 27-fold increase in cell death is observed in the mutant $(p<0.0003)$ at $13.5 \mathrm{dpc}$, whereas the TUNEL-positive cells increase 3.3-fold in the mutant at $\mathrm{PO}(p<0.0001)$. Statistical tests of significance were accomplished using a one-tailed Student's $t$ test. Error bars indicate SD.

yses of deep cerebellar cells show that immunopositive cells in mutants are significantly decreased compared with normal animals (Fig. 8C) $(p<0.0001)$. It appears that phospho-H3immunopositive cells are equivalently reduced in the EGL. However, the cell nuclei of this region are so tightly packed that calculating the percentile of positive cells was compromised by the difficulty of accurately assessing the total number of cells. Overall, these data demonstrate that the levels of proliferation are decreased in both the granule cells and deep cerebellar neurons of the mutant.

To assess the levels of apoptosis in the mutants, we undertook TUNEL analyses in embryonic and neonatal cerebella. The number of cells labeled by the TUNEL procedure increases in the mutant cerebellum at both $13.5 \mathrm{dpc}$ and P0 (Fig. 8D). These differences demonstrate clear statistical significance $(p<$ $0.0003)$. Therefore, the mutant cerebella are smaller in size as a result of both a decrease in cell proliferation and an increase in apoptosis.

\section{Discussion}

In this study, we demonstrate genetically that signaling via type I BMP receptors is required for the specification and differentiation of granule cells and that the receptor genes Bmprla and $B m p r 1 b$ are functionally redundant in this capacity. Abrogation of BMP signaling results in profound losses in the expression of transcription factors that regulate the differentiation of 
granule cells. Finally, migration of both Purkinje and granule cells are affected. These data genetically demonstrate that mutations in BMP signaling are epistatic to a number of fundamental development processes during cerebellar ontogeny.

Previous reports have suggested that BMP signaling via type I BMP receptors plays a critical role in granule cell development (Ming et al., 2002). Both Bmprla and Bmprlb are expressed in granule neuron precursors and in mature granule neurons in the developing cerebellum. These receptors are expressed during granule cell proliferation, migration, and differentiation. When a constitutively active Bmprla construct was introduced into the developing cerebellum, the cerebella showed a simplified folial pattern and ectopic granule neurons located deep in the cerebellar white matter. These data indicate that ectopic type I BMP receptor signaling can result in abnormal cerebellar development (Ming et al., 2002). However, these data do not distinguish whether the roles of type I receptors are equivalent or whether there are distinct regulatory roles for each type I BMP receptor. Differences in the ability of the type I receptors to induce distinct outcomes has been hypothesized based on overexpression or misexpression experiments (Zou et al., 1997; Chen et al., 1998), and recently in conditional knock-out experiments (Murali et al., 2005). Genetic experiments demonstrate that the two type I receptors can subserve distinct functions during the formation of the limb (Baur et al., 2000; Yi et al., 2000; Ahn et al., 2001). Alternatively, we have previously demonstrated functional redundancy of type I receptors in specifying dorsal interneuron populations of the spinal cord (Wine-Lee et al., 2004). This study demonstrates another example of a developmental system in which the role of type I BMP receptors are functionally redundant.

Loss of BMP signaling results in failure of granule cell differentiation. Granule cell progenitors are initially formed in the rhombic lip. Math1 is expressed in the rhombic lip in the early stage and is expressed later in the outer EGL; Math1 is turned off in postmitotic granule cells in the inner EGL (Akazawa et al., 1995; Helms and Johnson, 1998; Ben-Arie et al., 2000). Math1 is a specific cellular marker of mitotic granule cell precursors and plays an important part in the differentiation of the cerebellar granule cell progenitors (Alder et al., 1999; Gazit et al., 2004). Gene-targeting studies in the mouse have shown that the activity of Math1 is required for the generation of granule cell progenitors (Ben-Arie et al., 1997). The development of cerebellar granule neurons has been hypothesized to require a conserved BMPtriggered transduction pathway that involves Math1 activity (Alder et al., 1999).

Although Math1 expression is lost in the mutant rhombic lip (Fig. $4 A, B$ ), in the mutant $\mathrm{P} 0$ cerebella, we observe detectable but reduced expression of Math1 (Fig. 4C,D). This expression domain is found in a thin layer along the entire cerebellar cortical surface that corresponds to the location where the EGL would normally form. Furthermore, this expression domain extends ectopically into the mesencephalon alongside a migration route aberrantly taken by mutant granule cells. This Math1 expression domain does not necessarily lead to the induction of the entire granule cell differentiation program, because only a small patch of relatively normal EGL is formed. This small patch of EGL expresses markers of differentiated EGL, including Pax6 (Fig. $4 F$ ), but other Math1-expressing cells in this cerebellar cortical rim, outside of the thickened patch, do not express these factors. These data indicate that BMP signaling is required for Math1expressing cells to differentiate past the earliest stages of granule cell differentiation.
Interestingly, the P0 double knock-out appears, in many respects, similar to a normal fetal-stage cerebellum. For example, compare the foreshortened EGL of the mutant P0 phenotype (Fig. 2D) with the normal cerebellum of a $15.5 \mathrm{dpc}$ embryo (Fig. $1 C)$. This comparison suggests that the ontogeny of the mutant cerebella is developmentally delayed or stops prematurely. During normal EGL maturation, granule cell precursors migrate tangentially from the rhombic lip to cover the superficial zone of the cerebellar primordium (for review, see Sotelo, 2004). By $15 \mathrm{dpc}$, granule cell precursors have covered most of the cerebellar surface, following a lateromedial and posteroanterior direction. Therefore, a drastic reduction in the number of granule cell precursors, like that found in the mutant, would be expected to lead to a premature EGL phenotype. Unfortunately, additional studies to assess this hypothesis are not possible because of early postnatal lethality of the mutations.

Despite the disorganization observed, a small patch of normal EGL forms in the double knock-out mutants. One possible explanation for why this patch of apparently normal EGL forms is that a few cells escape Cre-mediated inactivation of Bmprla to form this layer. This hypothesis is corroborated by the observation that small numbers of phospho-Smad-positive cells are detected in the rhombic lip and early subpial granule cell migratory stream that gives rise to the EGL (Fig. $3 C, D$ ). This hypothesis is also consistent with the observation that the mutant EGL is prematurely stopped, because only a limited number of EGL cells are produced in the mutant before the complete elimination of BMP signaling.

A second possibility is suggested by the observation that the thickened EGL is juxtaposed against a grouping of Purkinje cells that form just under the surface of the cerebellar cortex in this region (Fig. $7 A, B$ ). Because it has been demonstrated that Purkinje cells are a source of the granule cell growth factor Shh, it is possible that only a small region of the EGL receives enough Shh for the EGL to proliferate (for review, see Ho and Scott, 2002; Sotelo, 2004). However, there is also a grouping of displaced Purkinje cells that lie next to the rostral cerebellar border, where the EGL is thin. Therefore, the explanation for a small patch of the thickened EGL cannot be solely explained by the availability of Shh from Purkinje cells. However, it would be interesting to determine whether Purkinje cells could rescue the EGL phenotype in slice cultures with mutant cerebella, and whether there are restricted domains in which the Purkinje cells or Shh alone could rescue the EGL proliferative phenotype in the mutants.

Is it possible that the EGL attracts the Purkinje cells, thus explaining the spatial juxtaposition of the EGL and the PCL despite the otherwise disorganized mutant cerebellum? This is unlikely, because the distribution of Purkinje cells in the BMP signaling mutant appear quite similar to the distribution found in Math1 knock-outs, that have no apparent EGL (Jensen et al., 2002), suggesting that the Purkinje cell distribution in mutants cannot entirely be explained by EGL chemoattraction.

Two pieces of evidence argue that BMP signaling does not have a particularly profound role in Purkinje cell formation. First, Purkinje cell formation and distribution in the BMP signaling mutant appear similar to that found in the Math1 knock-out, a mutant that only affects granule cell differentiation. Second, phospho-Smad immunostaining appears to be primarily restricted to differentiated granule cells, with little or no colabeling of phospho-Smad with calbindin-positive Purkinje cells. We cannot, however, rule out the possibility that a low level of BMP signaling is occurring that falls below the threshold of our phospho-Smad immunohistochemistry. Furthermore, condi- 
tional inactivation of the BMP signaling mediator Smad4 in postnatal animals results in Purkinje cell loss, suggesting that BMP signaling may be required for Purkinje cell maintenance (Zhou et al., 2003).

Interestingly, we do not see high levels of phospho-Smad staining in the outer EGL where proliferation is occurring. Previous data suggest that BMP signaling via Smad5 is required to induce the differentiation of granule cells (Rios et al., 2004). Our data are consistent with this interpretation, because it is likely that our phospho-Smad antibody does not distinguish between Smad1/5/8. Given that we do observe phospho-Smadimmunopositive cells in the inner EGL, a few cell thicknesses away, this observation raises an interesting question of how BMP signaling is so tightly regulated within this embryonic layer. The BMP factors Bmp2 and Bmp4 are expressed in the EGL, and Bmp7 is found in the adjacent PCL. Given the plethora of potential negative modulators of BMP signaling (for review, see von Bubnoff and Cho, 2001), it will be interesting to determine how this signaling pathway is so tightly regulated. These data, in conjunction with the BMP signaling mutant analyses, suggest that tight regulation of BMP signaling is required for the proper formation of the cerebellum.

\section{References}

Ahn K, Mishina Y, Hanks MC, Behringer RR, Crenshaw III EB (2001) BMPR-IA signaling is required for the formation of the apical ectodermal ridge and dorsal-ventral patterning of the limb. Development 128:4449-4461.

Akazawa C, Ishibashi M, Shimizu C, Nakanishi S, Kageyama R (1995) A mammalian helix-loop-helix factor structurally related to the product of Drosophila proneural gene atonal is a positive transcriptional regulator expressed in the developing nervous system. J Biol Chem 270:8730-8738.

Alder J, Cho NK, Hatten ME (1996) Embryonic precursor cells from the rhombic lip are specified to a cerebellar granule neuron identity. Neuron 17:389-399.

Alder J, Lee KJ, Jessell TM, Hatten ME (1999) Generation of cerebellar granule neurons in vivo by transplantation of BMP-treated neural progenitor cells. Nat Neurosci 2:535-540.

Amy WH, Katherine G, Andrew A, Trisha S, Jane EJ (2001) Overexpression of Math1 disrupts the coordination of neural differentiation in cerebellum development. Mol Cell Neurosci 17:671-682.

Anton M, Horky M, Kuchtickova S, Vojtesek B, Blaha O (2004) Immunohistochemical detection of acetylation and phosphorylation of histone $\mathrm{H} 3$ in cervical smears. Ceska Gynekol 69:3-6.

Aruga J, Yokota N, Hashimoto M, Furuichi T, Fukuda M, Mikoshiba K (1994) A novel zinc finger protein, zic, is involved in neurogenesis, especially in the cell lineage of cerebellar granule cells. J Neurochem 63:1880-1890.

Baur ST, Mai JJ, Dymecki SM (2000) Combinatorial signaling through BMP receptor IB and GDF5: shaping of the distal mouse limb and the genetics of distal limb diversity. Development 127:605-619.

Ben-Arie N, Bellen HJ, Armstrong DL, McCall AE, Gordadze PR, Guo Q, Matzuk MM, Zoghbi HY (1997) Math1 is essential for genesis of cerebellar granule neurons. Nature 390:169-172.

Ben-Arie N, Hassan BA, Bermingham NA, Malicki DM, Armstrong D, Matzuk M, Bellen HJ, Zoghbi HY (2000) Functional conservation of atonal and Math1 in the CNS and PNS. Development 127:1039-1048.

Chedotal A, Sotelo C (1992) Early development of olivocerebellar projections in the fetal rat using CGRP immunocytochemistry. Eur J Neurosci 4:1159-1179.

Chen D, Ji X, Harris MA, Feng JQ, Karsenty G, Celeste AJ, Rosen V, Mundy GR, Harris SE (1998) Differential roles for bone morphogenetic protein (BMP) receptor type IB and IA in differentiation and specification of mesenchymal precursor cells to osteoblast and adipocyte lineages. J Cell Biol 142:295-305.

Derynck R, Zhang YE (2003) Smad-dependent and Smad-independent pathways in TGF-beta family signalling. Nature 425:577-584.
Dodd J, Morton SB, Karagogeos D, Yamamoto M, Jessell TM (1988) Spatial regulation of axonal glycoprotein expression on subsets of embryonic spinal neurons. Neuron 1:105-116.

Easter Jr SS, Ross LS, Frankfurter A (1993) Initial tract formation in the mouse brain. J Neurosci 13:285-299.

Ebendal T, Bengtsson H, Soderstrom S (1998) Bone morphogenetic proteins and their receptors: potential functions in the brain. J Neurosci Res 51:139-146.

Engelkamp D, Rashbass P, Seawright A, van Heyningen V (1999) Role of Pax6 in development of the cerebellar system. Development 126:3585-3596.

Furley AJ, Morton SB, Manalo D, Karagogeos D, Dodd J, Jessell TM (1990) The axonal glycoprotein TAG-1 is an immunoglobulin superfamily member with neurite outgrowth-promoting activity. Cell 61:157-170.

Gazit R, Krizhanovsky V, Ben-Arie N (2004) Mathl controls cerebellar granule cell differentiation by regulating multiple components of the Notch signaling pathway. Development 131:903-913.

Grinspan JB, Coulalaglou M, Beesley JS, Carpio DF, Scherer SS (1998) Maturation-dependent apoptotic cell death of oligodendrocytes in myelin-deficient rats. J Neurosci Res 54:623-634.

Hatten ME, Heintz N (1995) Mechanisms of neural patterning and specification in the developing cerebellum. Annu Rev Neurosci 18:385-408.

Helms AW, Johnson JE (1998) Progenitors of dorsal commissural interneurons are defined by MATH1 expression. Development 125:919-928.

Heydemann A, Nguyen LC, Crenshaw III EB (2001) A regulatory region of the Brn4/Pou $3 f 4$ promoter directs expression to developing forebrain and neural tube. Dev Brain Res 128:83-90.

Ho KS, Scott MP (2002) Sonic hedgehog in the nervous system: functions, modifications and mechanisms. Curr Opin Neurobiol 12:57-63.

Hogan BL (1996) Bone morphogenetic proteins: multifunctional regulators of vertebrate development. Genes Dev 10:1580-1594.

Jensen P, Zoghbi HY, Goldowitz D (2002) Dissection of the cellular and molecular events that position cerebellar Purkinje cells: a study of the math1 null-mutant mouse. J Neurosci 22:8110-8116.

Lee MK, Tuttle JB, Rebhun LI, Cleveland DW, Frankfurter A (1990) The expression and posttranslational modification of a neuron-specific betatubulin isotype during chick embryogenesis. Cell Motil Cytoskeleton 17:118-132.

Lin JC, Cai L, Cepko CL (2001) The external granule layer of the developing chick cerebellum generates granule cells and cells of the isthmus and rostral hindbrain. J Neurosci 21:159-168.

Ming JE, Elkan M, Tang K, Golden JA (2002) Type I bone morphogenetic protein receptors are expressed on cerebellar granular neurons and a constitutively active form of the type IA receptor induces cerebellar abnormalities. Neuroscience 114:849-857.

Mishina Y, Hanks MC, Miura S, Tallquist MD, Behringer RR (2002) Generation of Bmpr/Alk3 conditional knockout mice. Genesis 32:69-72.

Murali D, Yoshikawa S, Corrigan RR, Plas DJ, Crair MC, Oliver G, Lyons KM, Mishina Y, Furuta Y (2005) Distinct developmental programs require different levels of Bmp signaling during mouse retinal development. Development 132:913-923.

Nagai T, Aruga J, Takada S, Gunther T, Sporle R, Schughart K, Mikoshiba K (1997) The expression of the mouse Zic1, Zic2, and Zic3 gene suggests an essential role for Zic genes in body pattern formation. Dev Biol 182:299-313

Phippard D, Lu L, Lee D, Saunders JC, Crenshaw III EB (1999) Targeted mutagenesis of the POU-domain gene, Brn4/Pou3f4, causes development defects in the inner ear. J Neurosci 19:5980-5989.

Ramon y Cajal S (1889) Sobre las fibras nerviosas de la capa granulosa del cerebelo. Rev Trim Histol Norm Pathol 3:4-5.

Rios I, Alvarez-Rodriguez R, Marti E, Pons S (2004) Bmp2 antagonizes sonic hedgehog-mediated proliferation of cerebellar granule neurones through Smad5 signalling. Development 131:3159-3168.

Soriano P (1999) Generalized lacZ expression with the ROSA26 Cre reporter strain. Nat Genet 21:70-71.

Sotelo C (2004) Cellular and genetic regulation of the development of the cerebellar system. Prog Neurobiol 72:295-339.

ten Dijke P, Miyazono K, Helden C-H (1996) Signaling via heterooligomeric complexes of type I and type II serine/threonine kinase receptors. Curr Opin Cell Biol 8:139-145. 
von Bubnoff A, Cho KW (2001) Intracellular BMP signaling regulation in vertebrates: pathway or network? Dev Biol 239:1-14.

Weis-Garcia F, Massague J (1996) Complementation between kinase defective and activation defective TGF-beta receptors reveals a novel form of receptor cooperativity essential for signaling. EMBO J 15:276-289.

Wilkinson DG, ed (1992) In situ hybridization: a practical approach. New York: Oxford UP.

Wine-Lee L, Ahn KJ, Richardson RD, Mishina Y, Lyons KM, Crenshaw III EB (2004) Signaling through BMP type 1 receptors is required for development of interneuron cell types in the dorsal spinal cord. Development 131:5393-5403.

Wingate RJ, Hatten ME (1999) The role of the rhombic lip in avian cerebellum development. Development 126:4395-4404.
Wrana JL, Attisano L, Wieser R, Ventura F, Massague J (1994) Mechanism of activation of the TGF-beta receptor. Nature 370:341-347.

Yi SE, Daluiski A, Pederson R, Rosen V, Lyons KM (2000) The type I BMP receptor BMPRIB is required for chondrogenesis in the mouse limb. Development 127:621-630.

Zhao GQ (2003) Consequences of knocking out BMP signaling in the mouse. Genesis 35:43-56.

Zhou YX, Zhao M, Li D, Shimazu K, Sakata K, Deng CX, Lu B (2003) Cerebellar deficits and hyperactivity in mice lacking Smad4. J Biol Chem 278:42313-42320.

Zou H, Wieser R, Massague J, Niswander L (1997) Distinct roles of type I bone morphogenetic protein receptors in the formation and differentiation of cartilage. Genes Dev 11:2191-2203. 